\title{
PENGEMBANGAN MEDIA PEMBELAJARAN POP UP BOX BERBASIS PROBLEM SOLVING PADA MATA PELAJARAN IPA FISIKA
}

\section{DEVELOPING POP UP BOX LEARNING MEDIA BASED ON PROBLEM SOLVING IN SCIENCE PHYSICS SUBJECT}

\author{
Nurul Muchlisa1), Santih Anggereni2), Ali Umar Dani'3), Suhardiman4) \\ 1,2,3,4)Fakultas Tarbiyah dan Keguruan Universitas Islam Negeri Alauddin Makassar \\ nurulmuchlisa201@gmail.com ${ }^{1)}$, santih.anggereni@uin-alauddin.ac.id ${ }^{2}$ ) \\ suhardiman.hardi@uin-alauddin.ac.id4)
}

\begin{abstract}
Abstrak
Media pembelajaran sebagai alat bantu dalam proses pembelajaran perlu dikembangkan sesuai dengan karakteristik peserta didik. Tujuan dilaksanakannya penelitian ini yaitu untuk mengetahui gambaran media pembelajaran yang memiliki kriteria valid, efektif, dan praktis. Pengembangan media pembelajaran ini menggunakan prosedur model 4D, yang terdiri dari Define, Design, Develop, Disseminate. Penelitian ini menggunakan subjek sejumlah 24 peserta didik yang berasal dari kelas VII 3 MTsN Barru, Kab. Barru pada semester ganjil. Pengumpulan data dilakukan dengan menggunakan lembar validasi media, lembar observasi, angket respon peserta didik, dan tes hasil belajar. Hasil penelitian dengan teknik analisis deskriptif diperoleh tingkat kevalidan $\mathrm{V}=0,89$ dapat dikatakan telah valid dan layak digunakan. Tingkat kepraktisan diperoleh $>50 \%$ dari respon peserta didik. sedangkan tingkat keefektifan diperoleh $80 \%$ peserta didik mendapatkan tes hasil belajar yang memuaskan sehingga dapat meningkatkan dan memecahkan masalah peserta didik. Berdasarkan penelitian yang telah dilakukan, media pembelajaran Pop Up Box berbasis problem solving yang dikembangkan dapat memenuhi kriteria kevalidan, kepraktisan, dan keefektifan.
\end{abstract}

Kata Kunci: media pembelajaran, Pop Up Box, problem solving

\begin{abstract}
Learning media as a tool in the learning process needs to be developed according to students' characteristics. The purpose of carrying out this research is to determine the description of learning media that has valid, effective, and practical criteria. The development of this learning media uses the $4 D$ model procedure, which consists of Define, Design, Develop, Disseminate. This study used the subject of a total of 24 students from class VII 3 MTsN Barru, Kab. Barru in odd semester. Data collection was carried out using media validation sheets, observation sheets, student response questionnaires, and learning outcomes tests. The results of research with descriptive analysis techniques obtained the validity level $V=0.89$ can be said to have been valid and fit for use. The level of practicality is obtained $>50 \%$ of the responses of students. while the level of effectiveness obtained $80 \%$ of students get a satisfactory learning outcome test so that it can improve and solve students' problems. Based on the research that has been done, the Pop Up Box learning media based on problem solving developed can meet the criteria of validity, practicality, and effectiveness.
\end{abstract}

Keywords: learning media, Pop Up Box, problem solving

How to Cite: Muchlisa, N., Anggereni, S., Dani, A. U., \& Suhardiman (2021). Pengembangan media pembelajaran Pop Up Box berbasis problem solving pada mata pelajaran IPA Fisika. Al asma: Journal of Islamic Education, 3(1), 97-109. 


\section{PENDAHULUAN}

Sarana mempersatukan setiap warga Negara dapat dilakukan melalui aspek pendidikan. Pendidikan adalah sebuah proses yang dilakukan sebagai bentuk pembelajaran kepada peserta didik untuk mencapai pemahaman terhadap sesuatu dan dapat mengembangkan kemampuan berpikir kritisnya (Ali, 2007). Pendidikan memiliki peranan penting bagi perdaban manusia karena merupakan hal yang diperlukan untuk setiap individu dalam memajukan kreativitas di dalam dirinya sehingga menjadi individu yang bemanfaat. Pendidikan adalah usaha sadar dan bertujuan unutk mengembangkan kulitas manusia (Djamarah \& Zain, 2010).

Berdasarkan UU RI No. 20 Tahun 2003 pasal 1 menyatakan bahwa, "Pendidikan adalah usaha sadar dan terencana untuk mewujudkan suasana belajar dan proses pembelajaran agar peserta didik secara aktif mengembangkan potensi dirinya untuk memiliki kekuatan spiritual keagamaan, pengendalian diri, kepribadian, kecerdasan, akhlak mulia, serta keterampilan yang diperlukan dirinya, masyarakat, bangsa dan negara”.Dan Pasal 31 ayat 1 UUD 1945 yang berbunyi : "Tiap-tiap warga negara berhak mendapatkan pendidikan."

Sasaran pendidikan adalah manusia, dimana manusia adalah pelaku, akan tetapi juga menjadi objek dalam pendidikan, sehingga hakikat dari belajar dapat dipahami dari segi kemanusiaan(Ikbal \& Khuzaimah, 2020).Setiap manusia wajib belajar untuk memperoleh ilmu pengetahuan sebagai upaya dalam meningkatkan derajat kehidupan. Hal ini telah dijelaskan dalam Al-Qur'an (Q.S Al Mujadalah, 58:11) yang berbunyi:

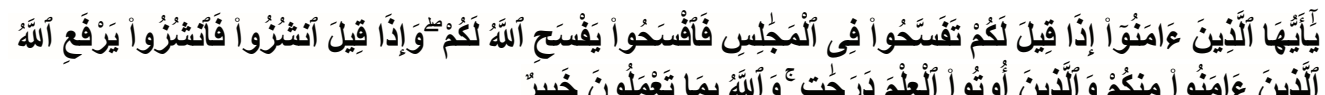

Artinya : "Hai orang-orang beriman apabila dikatakan kepadamu: "Berlapanglapanglah dalam majlis", maka lapangkanlah niscaya Allah akan memberi kelapangan untukmu. Dan apabila dikatakan: "Berdirilah kamu", maka berdirilah, niscaya Allah akan meninggikan orang-orang yang beriman di antaramu dan orang-orang yang diberi ilmu pengetahuan beberapa derajat. Dan Allah Maha Mengetahui apa yang kamu kerjakan" (Departemen Agama RI, 2017).

Pembelajaran IPA dalam hal ini adalah fisika dapat dilakukan dengan pola pembelajaran yang memberikan pengalaman belajar yang benar-benar nyata, sehingga peserta didik dapat dengan mudah mengaplikasikan pengetahuan yang diperolehnya dalam kehidupan sehari-hari. Konsep-konsep dalam pembelajaran fisika yang bersifat hafalan, dengan banyaknya rumus-rumus dan istilah-istilah verbal dapat menyulitkan peserta didik untuk memahaminya (Mahayani, Irwandani, Yuberti, \& Widayanti, 2018). Dengan demikian, untuk menyiasati agar pembelajaran dapat dipahami dengan mudah oleh peserta didik, pendidik dapat menggunakan media pembelajaran yang bervariasi sebagai bentuk perbaikan atas kualitas pembelajaran.

Media pembelajaran adalah sebuah alat bantu yang dapat dipakai oleh guru dalam mengantarkan sebuah materi pelajaran kepada peserta didik. Hal yang perlu diperhatikan dalam memilih media pembelajaran adalah penyesuaian terhadap materi yang diajarkan dengan karakteristik peserta didik. Hal ini dilakukan agar kegiatan pembelajaran dengan penggunaan media dapat berjalan aktif dan peserta didik dapat terlibat langsung sesuai dengan perencanaan (Nugroho, Raharjo, \& Wahyuningsih, 2013). 
Hasil wawancara kepada peserta didik MTsN Barru yang mengungkapkan bahwa, "Proses pembelajaran IPA Fisika di kelas VII MTsN Barru sudah berjalan cukup baik namun masih terdapat kekurangan. Kekurangan yang diperoleh dalam pembelajaran yakni peserta didik lebih menyukai pembelajaran yang interaktif seperti bermain game ataupun belajar dengan menggunakan media yang menarik sehingga peserta didik ingin guru mengembangkan pembelajarannya." Sejalan dengan pernyataan tersebut guru mata pelajaran mengatakan, "Sampai saat ini media pembelajaran yang digunakan, khususnya pada materi IPA Fisika masih kurang beragam, hanya buku dan powepoint yang biasanya disusun oleh guru". Pada kenyataannya, penggunaan buku paket yang cenderung memuat materi dan gambar yang kurang menarik lebih sering digunakan dibanding dengan media powerpoint. Hal ini terjadi disebabkan fasilitas penggunaan powerpoint pada proses pembelajaran masih kurang. Diketahui bahwa pembelajaran yang diberlangsung di MTsN Barru lebih berfokus kepada guru dan kurang penggunaan media yang bervariasi. Keadaan ini menyulitkan peserta didik untuk memahami konsep pelajaran itu sendiri. Selain itu, perasaan bosan dan kurang motivasi dapat dengan mudah dirasakan, sebab tidak memberikan kebebasan dan keleluasaan kepada peserta didik dalam belajar.

Berdasarkan uraian yang telah dipaparkan, inovasi dalam pembelajaran IPA Fisika perlu dilakukan terutama dalam penggunaan media pembelajaran. Penggunaan media dalam pembelajaran dapat menjadi sarana dan membantu guru untuk menyampaikan materi yang dimaksud. Selain itu, penggunaan media dapat memberi kesempatan kepada peserta didik untuk aktif dalam proses pembelajaran. Menurut Romanvican, Mundilarto, Supahar, dan Istiyono (2020) penggunaan media pembelajaran dalam menyampaikan materi harus melibatkan peserta didik. Salah satunya, yaitu media pop-up box.

Media Pop Up Box merupakan media dengan tampilan tiga dimensi yang digunakan sebagai hiasan buku, kartu ucapan, ataupun hadiah pada kotak. Ketika membuka Pop Upakan menarik perhatian dengan tampilan tiga dimensinya (Rachmawati, Pramesti, Chrisnawati, \& Fitriana, 2019). Media Pop Up Box memiliki bentuk kotak dengan unsur tiga dimensi dan memiliki bagian yang dapat bergerak. Unsur tiga dimensi ini memberi tampilan visual cerita yang menarik untuk dilihat.

Penggunaan Pop Up dapat ditunjang dengan penggunaan model pembelajaran yang bervariasi, yaitu salah satunya problem solving. Problem solving merupakan pembelajaran yang memfokuskan peserta didik dalam memecahkan masalah yang dapat dilakukan secara berkelompok ataupun secara individu (Febriyanti, Rudibyani, \& Sofia, 2017).Polya berpendapat bahwa ada empat langkah dalam model Problem solving yaitu (1) memahami masalah (Understanding), (2) menentukan rencana strategi pemacahan masalah (Planning), (3) menyelesaikan strategi penyelesaian masalah (Solving), memeriksa kembali jawaban yang diperoleh (Checking) (Nurliawaty, Mujasam, Yusuf, \& Widyaningsih, 2017).

Tidak semua materi IPA Fisika dapat menggunakan media pembelajaran Pop Up Box. Tujuan dari media ini adalah memudahkan peserta didik untuk menyusun pemahaman-pemahaman konsepnya secara utuh, dengan memahami materi-materi yang dapat diterapkan dalam kehidupan sehari-hari sehingga tidak hanya sekedar menghafal. Melalui penggunaan media ini, diharapkan motivasi belajar peserta didik dapat ditingkatkan. 
Penelitian sebelumnya yang dilakukan oleh Safri, Sari, dan Marlina (2017) pernah melakukan penelitian yang serupa. Hasil penelitiannya menyimpulkan rata-rata validasi yang diperoleh sangat layak dan telah layak diuji coba lebih lanjut untuk melihat efektivitas dalam pembelajaran. Penelitian tersebut juga mengembangkan pop-up hanya saja dalam bentuk buku, yaitu, mengembangkan pop-up book. Sejalan dengan penelitian Aisyah (2018) bahwa tingkat validasi media di atas rata-rata sehingga media pembelajaran ini dikatakan sangat layak, efektif dan menarik digunakan sebagai sumber pembelajaran fisika.

Berdasarkan uraian latar belakang yang telah dipaparkan, peneliti tertarik untuk mengembangkan media pembelajaran IPA Fisika dengan judul penelitian "Pengembangan Media Pembelajaran Pop-Up Box berbasis Problem Solving Pada Mata Pelajaran IPA Fisika". Penelitian ini bertujuan untuk mengembangkan media pembelajaran Pop Up Box berbasis problem solving pada mata pelajaran IPA fisika yang memenuhi kriteria valid, praktis dan efektif.

\section{METODE PENELITIAN}

Penelitian ini adalah penelitian pengembangan (Research and Development). Penelitian ini dilakukan untuk menghasilkan sebuah produk, yaitu media pembelajaran IPA Fisika. Produk yang dihasilkan akan divalidasi oleh tiga orang validator yang terdiri dari dua orang dosen dan satu orang guru mata pelajaran. Selanjutnya, produk akan diujicobakan pada peserta didik yang berasal dari MTsN Barru Kab. Barru pada kelas VII tahun ajaran 2019/2020.

Pengembangan media ini menggunakan model 4D. Model 4D dikenal juga dengan model Thiagarajan dan Semmel. Model ini memiliki 4 tahapan, yaitu define (pendefinisian), design (perencanaan), development (pengembangan), dan desiminate (penyebaran) (Rafiqah, 2013).

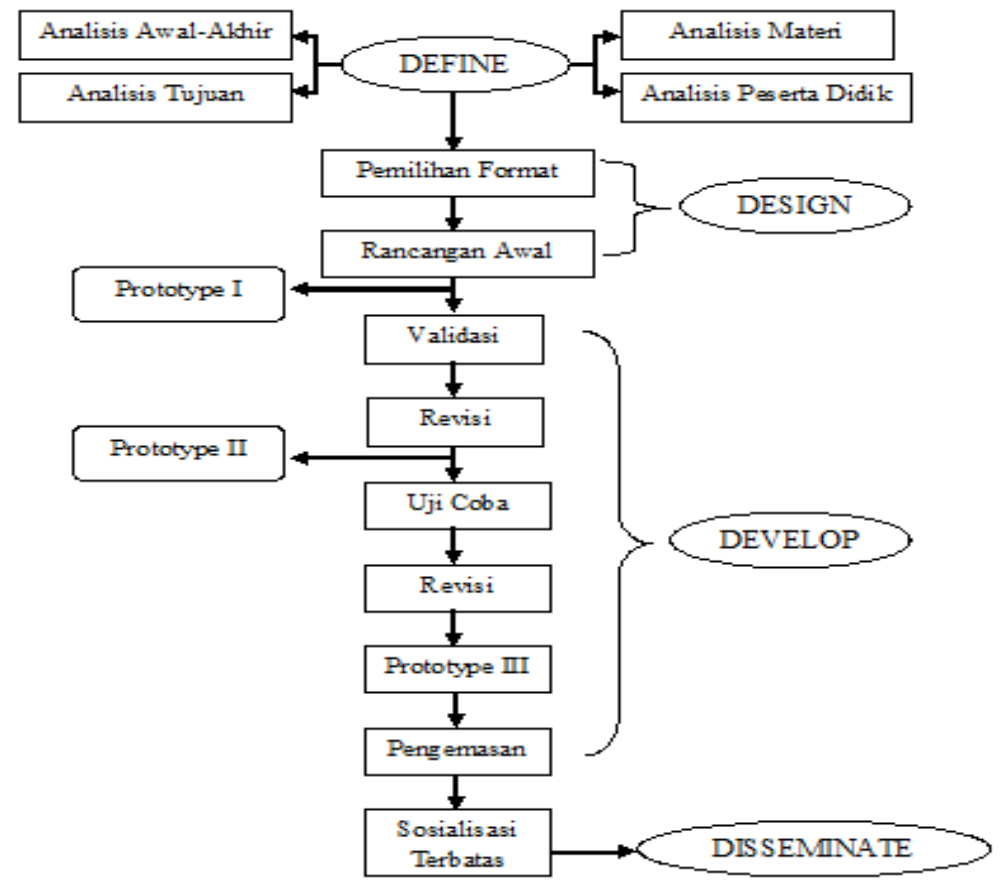

Gambar 1. Bagian prosedur pengembangan 4-D 
Instrumen yang dipakai untuk mengumpulkan data adalah lembar validasi produk yang terdiri dari aspek penyajian, kelayakan isi, dan bahasa. Terdapat pula lembar angket respon peserta didik untuk mengetahui respon terhadap produk dan lembar observasi untuk mengetahui kepraktisan penggunaan produk dalam proses pembelajaran. Tingkat keberhasilan produk dapat dilihat pada hasil belajar peserta setelah menggunakan produk tersebut melalui instrument tes hasil belajar yang akan diberikan.

Analisis data yang digunakan yaitu analisis statistik deskriptif. Kategori respon peserta didik dan hasil observasi disesuaikan dengan rentang kategori berikut ini:

Tabel 1. Kategori Kepraktisan Produk

\begin{tabular}{cll}
\hline No & Rumus & Klasifikasi \\
\hline 1 & $\bar{X}>\bar{X}_{l}+1,8 \times \mathrm{sb}_{\mathrm{i}}$ & Sangat baik \\
2 & $\bar{X}_{l}+0,6 \times \mathrm{xbi}<\mathrm{X} \leq \bar{X}_{l}+1,8 \times \mathrm{sb}_{\mathrm{i}}$ & Baik \\
3 & $\bar{X}_{l}-0,6 \times \mathrm{xbi}<\mathrm{X} \leq \bar{X}_{l}+0,6 \mathrm{xb}_{\mathrm{i}}$ & Cukup \\
4 & $\bar{X}_{L}-1,8 \times \mathrm{xbi}<\mathrm{X} \leq \bar{X}_{l}-0,6 \mathrm{x} \mathrm{sb}_{\mathrm{i}}$ & Kurang \\
5 & $\bar{X} \leq \bar{X}_{l}-1,8 \times \mathrm{sb}_{\mathrm{i}}$ & Sangat kurang \\
\hline
\end{tabular}

Keefektifan produk yang dihasilkan dilihat pada ketuntasan hasil belajar peserta didik (Nurfillaili, Yusuf, \& Santih, 2016). Adapun kriteria keefektifan terpenuhi apabila peserta didik mendapatkan skor minial KKM, yaitu 75 dengan ketuntasan lebih besar atau sama dengan $80 \%$.

\section{HASIL DAN PEMBAHASAN}

Media pembelajaran ini dikembangkan dengan model desain 4D yang terdiri dari define, design, development, dan dessiminate. Tahapan-tahapan yang dilalui saat proses pengembangan media beserta analisisnya dapat diuraikan sebagai berikut:

\section{Tahapan Pendefinisian (Define)}

Tahapan define adalah tahapan memutuskan dan menentukan syarat-syarat pembelajaran. Tahap ini, meliputi lima langkah pokok, yaitu: analisis awal-akhir, analisis tujuan, analisis peserta didik, analisis materi dan konsep akhir.

Analisis awal-akhir dilakukan untuk menentukan masalah mendasar dalam pengembangan media pembelajaran Pop Up Box berbasis Problem Solving. Berdasarkan analisis awal-akhir yang telah dilakukan, diperoleh hasil bahwa permasalahan yang menjadi landasan dalam pengembangan media pembelajaran ini adalah kurangnya variasi media pembelajaran, dalam hal ini hanya buku dan powerpoint. Dimana guru mengalami kesulitan untuk menggunakan powerpoint disetiap pembelajaran dikarenakan fasilitas sekolah di MTsN Barru yang kurang mendukung hal tersebut. Dengan demikian, pengembangan media pembelajaran ini bertujuan untuk menghasilkan suatu produk dalam bentuk Pop Up Box berbasis problem solving yang dapat dijadikan salah satu alternatif media dalam proses pembelajaran.

Selain itu, dalam proses define, peneliti juga menganalisis peserta didik sehingga pengembangan media ini sesuai dengan karakteristik peserta didik. Karakteristik yang dimiliki oleh kelas VII cenderung bersifat kanak-kanak dan masih berada pada fase peralihan dari sekolah dasar ke sekolah menengah pertama. Oleh karena itu, media yang dibutuhkan adalah media dengan berbagai bentuk dan sesuatu yang baru bagi peserta didik. Pemilihan media pembelajaran ini disesuaikan dengan karakteristik yang dimiliki 
oleh peserta didik, dan memuat materi tentang pemanasan global dikarenaka materi ini banyak menganalisis tentang permasalahan dalam kehidupan sehari-hari, dan dapat disajikan dalam bentuk Pop Up Box.

\section{Tahapan Design (Perancangan)}

Tahapan design adalah tahapan untuk merancang media yang akan dikembangkan. Hal yang dilakukan adalah memilih format media dan merancang awal media. Media pembelajaran ini memuat beberapa komponen yaitu, cover, materi, gambar, dan hiasan dalam media.

Perancangan cover media disesuaikan dengan karakter isi media yaitu pemanasan global. Rancangan cover media memberikan sentuhan gambar bumi, pemanasan global, lambing institusi, tidak lupa nama, nomor induk, dan jurusan peneliti dicantumkan. Selain itu, bagian-bagian materi yang ada di dalam media dimasukkan, terdiri dari (1) Pemanasan Global, (2) Efek Rumah Kaca, (3) Dampak Pemanasan Global, (4) Upaya Penanggulangan Pemanasan Global. Gambar yang akan dibuat timbul (Pop Up) adalah gambar menanam pohon, seorang anak yang bersepeda, hemat listrik, membuang sampah pada tempatnya. Adapun hiasannya adalah origami yang dapat ditarik bergerak ataupun dibuka. Fungsi dari origami ini adalah hiasan untuk setiap layer dalam kotak Pop Up. Selain itu, dalam layer terdapat materi dan beberapa permasalahan yang akan dipecahkan peserta didik sesuai dengan materi yang telah ditentukan sebelumnya. Tahap ini adalah tahap Prototype I sebagai rancangan awal, sebagaimana yang terlihat pada gambar berikut ini:

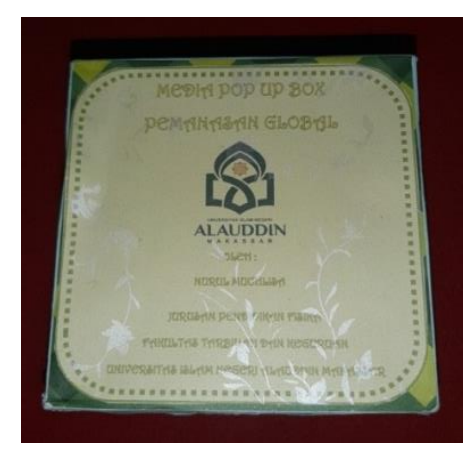

Gambar 2 : Cover bagian tutup Pop Up Box

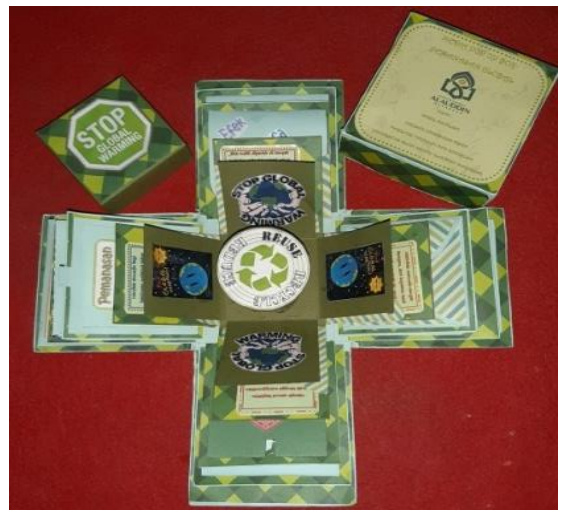

(a)

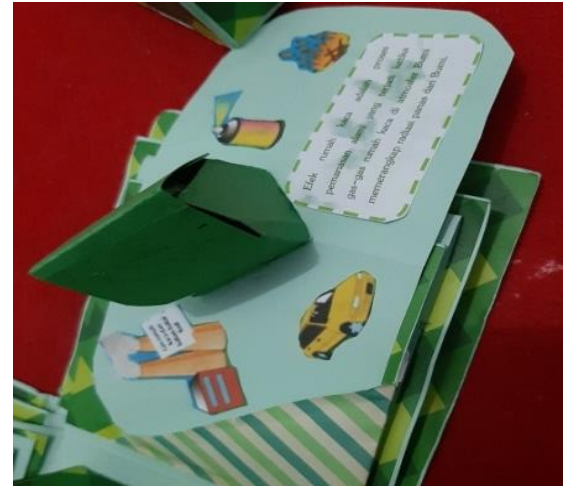

(b)

Gambar 3: Prototype I, (a) desain isi, (b) desain materi berbentuk Pop Up 


\section{Tahapan Development}

Tahap development menghasilkan prototype I dan prototype II setelah revisi dari beberapa ahli dan praktisi pada saat menguji kelayakan modul yang digunakan di sekolah. Tahap ini dilakukan validasi oleh 3 orang validator serta proses uji coba produk. Aspek yang divalidasi oleh 3 orang validator yaitu, aspek penyajian, kelayakan isi, dan bahasa. Berdasarkan penilaian yang telah dilakukan, maka diperoleh:

\begin{tabular}{|c|c|c|c|}
\hline No & Aspek validasi & V & Keterangan \\
\hline 1 & Penyajian & 0.92 & Validitas Tinggi \\
\hline 2 & Kelayakan Isi & 0.87 & Validitas Tinggi \\
\hline 3 & Kebahasaan & 0.85 & Validitas Tinggi \\
\hline & Rerata & 0.89 & Validitas Tinggi \\
\hline
\end{tabular}

Berdasarkan tabel 2 di atas, diperoleh hasil validasi $V=0.89$. Hasil validasi ini termasuk dalam kategori "Validitas Tinggi" (>0,8) (Retnawati, 2016), sehingga disimpulkan bahwa media yang dikembangkan telah memenuhi kriteria valid dan dapat dilanjutkan ke tahap berikutnya yaitu tahap uji coba terbatas. Media pembelajaran Pop Up Box berbasis Problem Solving yang telah melalui tahap validasi dan revisi berdasarkan saran dan komentar validator disebut Prototype II. Adapun bentuk media yang dimaksud sebagai berikut.

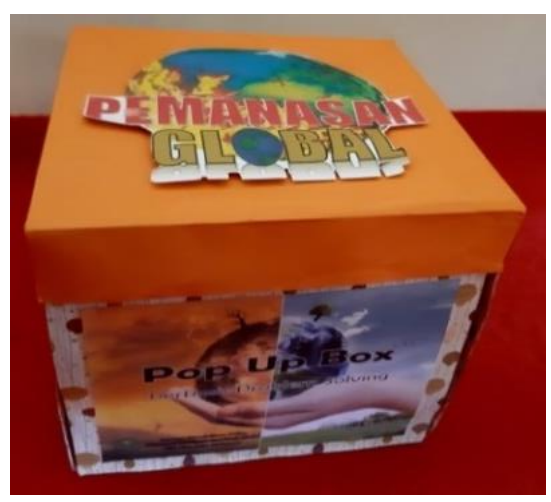

(a)

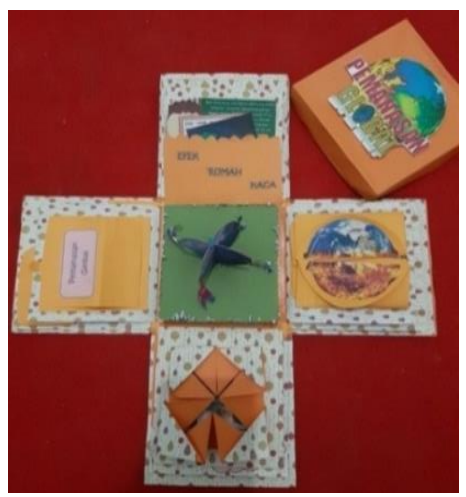

(b)

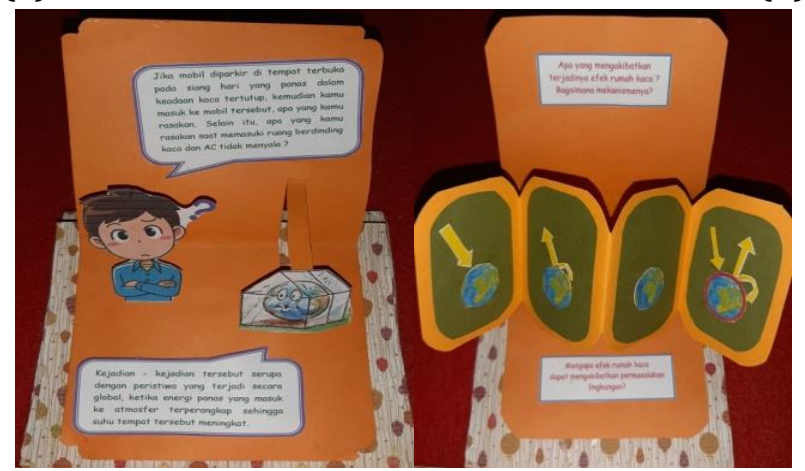

(c) 


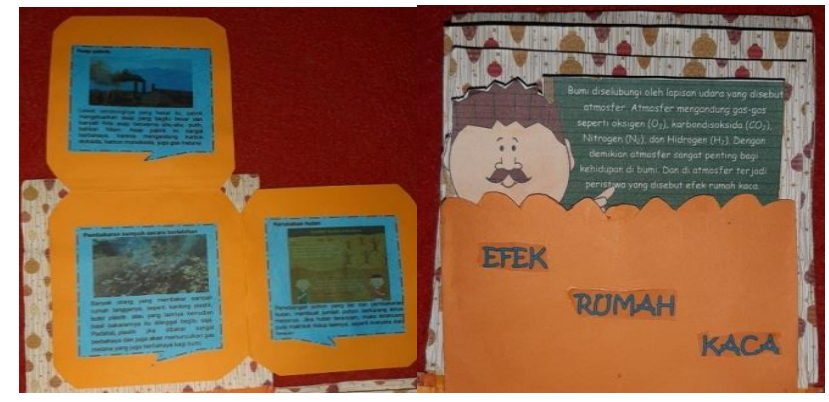

(d)

Gambar 3. Prototype II, (a) cover, (b) isi, (c) soal/masalah, dan (d) materi

Kevalidan media pembelajaran dapat ditentukan berdasarkan kriteria yang telah ditetapkan sebelumnya, yaitu mencapai lebih dari 75\%. Apabila kriteria tersebut terpenuhi, maka dapat dinyatakan bahwa media yang dikembangkan masuk dalam kategori valid. Namun, apabila tidak mencapai nilai validasi $75 \%$ maka harus dilakukan revisi yang sesuai dengan saran dari validator ataupun memperhatikan aspek-aspek yang membuat nilai validasinya tidak terpenuhi. Setelah itu, barulah kemudian melakukan validasi ulang sebagai bentuk penilaian kembali atas revisi yang telah dilakukan. Tahap ini terus berlangsung untuk mencapai nilai validasi yang sesuai dengan kriteria (Jusniar, Side, \& Anwar, 2014).

Berdasarkan hasil validasi media pembelajaran Pop Up Box berbasis problem solving yang telah mencapai kriteria "validitas tinggi" dapat dikatakan valid dan telah layak untuk dipakai pada proses pembelajaran. Penelitian ini didukung oleh penelitian yang telah dilakukan oleh Aisyah (2018), yang mengungkapkan presentasi dari validasi media pembelajaran sangat layak, efektif, dan menarik untuk diterapkan. Penelitian ini juga sejalan dengan pendapat Sutikno dalam (Sinurat, Syahputra, \& Rajagukguk, 2015) yang mengatakan bahwa kelayakan suatu media layak dapat dilihat apabila media tersebut mendukung isi materi pembelajaran.

Setelah melalui tahap validasi dan menghasilkan prototype II, maka dilanjutkan ke tahap uji coba terbatas. Tahap uji coba terbatas dilakukan dengan memakai media Pop Up Box berbasis problem solving pada saat pembelajaran berlangsung. Uji coba ini dilakukan kepada peserta didik sebanyak 24 orang di kelas $\mathrm{VII}_{3}$ MTsN Barru pada tahun ajaran 2019/2020

Pada tahap ini diperoleh gambaran hasil kepraktisan dan keefektifan media yang dikembangkan. Tujuan penggunaan media pembelajaran untuk membantu guru dalam menyampaikan materi dan mendorong proses pembelajaran pada peserta didik agar lebih termotivasi untuk belajar. Manfaat lainnya dapat memberikan kemudahan kepada peserta didik dalam memahami materi yang disampaikan oleh guru (Dewani, Kisyani, \& Hendratno, 2020).

Kriteria kualitas kepraktisan media pembelajaran dapat dilihat pada tingkat kemudahan guru dan peserta didik dalam menggunakannya. Menurut Wamalwa \& Wamalwa (2014)siswa dapat memahami konsep dengan baik apabila materi yang diajarkan dibantu dengan penggunaan media. Selain itu, menurutnya kelas akan lebih ramai dan peserta didik akan lebih aktif apabila memanfaatkan media dalam proses pembelajaran. Sejalan dengan, hasil penelitian de León, Saorin, de la Torre-Cantero, Meier, 
dan Marrero (2019)yang mengungkapkan pemanfaatan teknologi dan media ketika proses pembelajaran berlangsung akan dapat mengembangkan kemampuan peserta didik dan dapat menjadikan peserta didik lebih mandiri ketika melaksanakan pekerjaannya.

Kriteria kepraktisan media pembelajaran adalah jika 50\% peserta didik memberi penilaian yang positif terhadap aspek-aspek yang ada pada lembar angket respon(Fitria, 2017).

Berdasarkan angket yang diberikan kepada peserta didik, diperoleh hasil respon kepraktisan media pembelajaran sebagai berikut:

\begin{tabular}{cccc}
\multicolumn{4}{c}{ Tabel 3. Rekapitulasi Angket Respon Peserta Didik } \\
\hline Rentang & $f$ & $\%$ & Kategori \\
\hline $\mathrm{X}>68$ & 11 & 45,83 & Sangat Positif \\
$56<\mathrm{X} \leq 68$ & 13 & 54,17 & Positif \\
$44<\mathrm{X} \leq 56$ & 0 & 0 & Cukup Positif \\
$32<\mathrm{X} \leq 44$ & 0 & 0 & Kurang Positif \\
$\mathrm{X} \leq 32$ & 0 & 0 & Negatif \\
\hline Jumlah & 24 & 100 & \\
\hline
\end{tabular}

Berdasarkan data diatas, diperoleh bahwa dari 24 siswa, peserta didik yang memberi respon sangat positif sebanyak 11 orang dengan presentase 45,83\%, respon positif sebanyak 13 orang dengan presentase $54,17 \%$, serta tidak ada peserta didik yang memberi respon cukup positif, kurang positif ataupun negatif. Hal ini menunjukkan bahwa rata-rata peserta didik memberi penilaian respon positif sehingga media yang dikembangkan memberikan dampak positif kepada peserta didik.

Dari hasil analisis data, 100\% respon positif dari peserta didik. Aspek-aspek pernyataan yang mendapatkan respon positif dari peserta didik, yaitu:

1) Media Pop Up Boxmemberi kemudahan untuk memahami materi pemanasan global

2) Ilustrasi/gambar mendorong motivasi untuk mempelajari materi pemanasan global

3) Media Pop Up Boxmemberikan semangat belajar

4) Media Pop Up Boxtidak membosankan karena desain yang menarik

5) Ilustrasi/gambar yang ada pada media Pop Up Box terlihat nyata

6) Bentuk gambar yang ada pada media Pop Up Boxmenyenangkan dan menambah rasa keingintahuan

Selain itu, hasil observasi peserta didik juga menunjukkan hal yang sama, yang ditunjukka pada tabel berikut:

\begin{tabular}{cccc} 
Tabel 4. Rekapitulasi Hasil Observasi Peserta Didik \\
\hline Rentang & $F$ & $\%$ & Kategori \\
\hline $\mathrm{X}>23$ & 11 & 45,83 & Sangat Aktif \\
$19<\mathrm{X} \leq 23$ & 9 & 37,5 & Aktif \\
$15<\mathrm{X} \leq 19$ & 4 & 16,67 & Cukup Aktif \\
$11<\mathrm{X} \leq 15$ & 0 & 0 & Kurang Aktif \\
$\mathrm{X} \leq 11$ & 0 & 0 & Tidak Aktif \\
\hline Jumlah & 24 & 100 & \\
\hline
\end{tabular}

Berdasarkan tabel 4,diketahui bahwa 11 peserta didik dengan presentase 45,83\% sangat aktif, 9 peserta didik dengan presentase 37,5\% aktif, 4 peserta didik dengan presentase $16,67 \%$ cukup aktif pada saat proses pembelajaran. Diketahui pula bahwa tidak ada peserta didik yang kurang aktif maupun tidak aktif. Hasil ini memberikan 
kesimpulan bahwa dengan menggunakan media pembelajaran Pop Up Boxberbasis problem solving dapat meningkatkan keaktifan peserta didik dalam belajar. Penelitian yang mendukung hasil ini adalah penelitian yang pernah dilakukan oleh Fibriani, Damris, dan Risnita (2014). Pada penelitian tersebut disimpulkan bahwa aktivitas peserta didik dipengaruhi oleh modul yang telah dikembangkan. Adapula penelitian (Setyawan, 2014) yang telah mengembangkan modul berbasis Pop Up book untuk meningkatkan aktivitas peserta didik dari aspek berbicara dan berdiskusi.

Pengujian keefektifan media, dapat dilakukan dengan menggunakan tes hasil belajar setelah peserta didik mengikuti pembelajaran dengan menggunakan media yang dikembangkan. Trianto (2009) dalam Fitria (2017) memberikan pendapatnya bahwa pembelajaran yang efektif adalah pembelajaran yang memenuhi kriteria berikut ini: 1) kegiatan pembelajaran peserta didik lebih tinggi dibanding presentase kegiatan lainnya; 2) peserta didik dapat melaksanakan tugas yang diberikan; 3) kemampuan pesetrta didik terhadap materi yang diajarkan tepat; dan 4) suasana pembelajaran yang dihasilkan lebih akrab dan positif. Hasil ini didukung oleh penelitian Ningsih, Riyanto, dan Suyanto (2019) yang menyatakan secara umum, media pembelajaran efektif digunakan dakam meningkatkan kreatifitas dan hasil belajar peserta didik. Maka dari itu dilakukan tes hasil belajar untuk melihat keefektifan dari media pembelajaran yang telah dikembangkan.

Keefektifan pembelajaran dapat ditentukan melalui kriteria ketuntasan minimalhasil belajar peserta didik, yaitu mencapai 80\% skor KKM yang ditetapkan, dalam hal ini sebesar 75 (Fitria, 2017). Berdasarkan tes hasil belajar, diperoleh nilai keefektifan media pembelajaran sebagai berikut:

Tabel 5. Kategorisasi Ketuntasan Hasil Belajar Peserta Didik

\begin{tabular}{cccc}
\hline Rentang & $F$ & $\%$ & Kategori \\
\hline $93-100$ & 8 & 33,33 & Sangat Baik \\
$84-92$ & 10 & 41,67 & Baik \\
$75-83$ & 6 & 25 & Cukup \\
$<75$ & 0 & 0 & Kurang \\
\hline Jumlah & 24 & $100 \%$ & \\
\hline
\end{tabular}

Berdasarkan tabel 6, diketahui bahwa peserta didik yang mencapai kriteria sangat baik sebanyak 8 orang dengan presentase 433,33\%. Kriteria baik sebanyak 10 orang dengan presentase sebesar 41,67\%. Kriteria cukup sebanyak 6 orang dengan presentase $25 \%$, sehingga tidak ada peserta didik yang tidak mencapai nilai skor minimal yang telah ditetapkan, dalam hal ini dibawah 75.

Media pembelajaran mempunyai fungsi dan manfaat sebagai sarana bagi guru unutk memberikan materi pelajaran menjadi lebih menarik dan tidak monoton (Suarti, Qaddaf, Rivai, \& Jusriana, 2020). Hasil penelitia ini didukung oleh penelitian Mahayani, Irwadani, Yuberti, dan Widyawati (2018) bahwa penggunaan media pembelajaran kotak Pop Up berbasis problem solving dinyatakan sangat layak dan menarik untuk pembelajaran fisika berdasarkan hasil validitas media tersebut. Muslimin, Rafiqah, dan Ikbal (2018) juga mengungkapkan hasil penelitiannya bahwa penggunaan media LKPD efektif digunakan dalam meningkatkan dan memecahkan masalah peserta didik. Begitu pula dengan penelitian Ariskasari (2019) bahwa dengan mengembangkan modul matematika yang berbasis problem solving polya untuk materi vector dapat digunakan dalam pembelajaran berdasarkan kriteria keefektifan yang mencapai 61\%. Pengembangan media pada 
penelitian ini dilakukan dengan memperhatikan materi yang disajikan yaitu pemanasan global, sehingga dalam pengembangannya, gambar-gambar dalam pop-up box tersebut disesuaikan dengan materi.

\section{SIMPULAN}

Prosedur pengembangan media pebelajaran Pop Up Boxberbasis problem solving terdiri dari (1) Define (Pendefinisian), (2) Design (Perancangan), (3) Develop (Pengembangan), dan (4) Disseminate (Penyebaran). Berdasarkan analisis yang dilakukan pada lembar validasi yang telah dinilai oleh ketiga validator, media yang dikembangkan memenuhi kriteria sangat valid, sehingga layak untuk digunakan. Pada penggunaan media ini, didapatkan peserta didik sangat aktif mengikuti pembelajaran melalui lebar observasi, sehingga media dikatakan dapat dikatakan praktis. Adapun hasil belajar yang diperoleh setelah penggunaan media ini memperoleh nilai rata-rata yang sangat baik. Oleh karena itu, berdasarkan penelitian yang telah dilakukan, media pembelajaran Pop Up Box berbasis problem solving yang dikembangkan dapat memenuhi kriteria kevalidan, kepraktisan, dan keefektifan untuk digunakan dalam proses pembelajaran.

\section{DAFTAR PUSTAKA}

Aisyah, A. M. (2018). Pengembangan media pop up box pada mata pelajaran matematika untuk siswa kelas III Sekolah Dasar. Universitas Muhammadiyah Malang.

Ali, M. (2007). Ilmu dan aplikasi pendidikan. Bandung: Imperial Bhakti Utama.

Ariskasari, D. (2019). Pengembangan modul matematika berbasis problem solving polya pada materi vektor. UIN Raden Intan Lampung.

de León, A. B., Saorin, J. L., de la Torre-Cantero, J., Meier, C., \& Marrero, E. G. (2019). The classroom as a makerspace: use of tablets and cutting plotter to create pop-up cards in educational environments. International Journal of Emerging Technologies in Learning, 14(10), 116-131. https://doi.org/10.3991/ijet.v14i10.10284.

Departemen Agama RI. (2017). Al-Qur'anul Karim Terjemahan \& 319 Tafsir Tematik. Bandung: PT. Cordoba Internasional-Indonesia.

Dewani, H. W., Kisyani, \& Hendratno. (2020). Development of media pop up card folklore to improve the critical reading skills of grade-IV students elementary school. International Journal of Innovative Science and Research Technology, 5(1), 901-907. Retrieved from https://www.ijisrt.com/development-of-media-pop-up-cardfolklore-to-improve-the-critical-reading-skills-of-gradeiv-students-elementaryschool.

Djamarah, S. ., \& Zain, A. (2010). Strategi belajar mengajar. Jakarta: Rineka Cipta.

Febriyanti, F., Rudibyani, R. B., \& Sofia, E. (2017). Penerapan model pembelajaran problem solving untuk meningkatkan hasil belajar IPA siswa kelas V. Jurnal Pendidikan Dan Pembelajaran Kimia, 6(2), 199-211. https://doi.org/10.28926/briliant.v2i2.46.

Fibriani, L., Damris, M., \& Risnita, R. (2014). Pengembangan multimedia pembelajaran interaktif untuk meningkatkan motivasi dan hasil belajar siswa pada materi kesetimbangan kimia SMA. Edu-Sains: Jurnal Pendidikan Matematika Dan Ilmu Pengetahuan Alam, 3(1), 1-5. https://doi.org/10.22437/jmpmipa.v3i1.1760.

Fitria, A. D. (2017). Pengembangan media gambar berbasis potensi lokal pada pembelajaran materi keanekaragaman hayati di kelas X SMAN 1 Pitu Riase Kab. Sidenreng Rappang. Diss Universitas Islam Negeri Alauddin Makassar, 4(2), 14-28. 
Ikbal, M. S., \& Khuzaimah, A. U. (2020). Pengembangan modul pembelajaran IPA fisika berbasis Pop-up Book. Jurnal Pendidikan Fisika, Volume 8(No 1), 53-60. Retrieved from http://journal.uin-alauddin.ac.id/indeks.php/PendidikanFisika\%0Ap-ISSN

Jusniar, Side, S., \& Anwar, M. (2014). Pengembangan perangkat assesment berbasis Keterampilan Generik Sains (KGS) pada mata kuliah praktikum kimia fisika II. J.Pen.Pend.Kim, 1(1), 35-42. $\quad$ Retrieved from https://ejournal.unsri.ac.id/index.php/jurpenkim/article/view/2382/1256.

Mahayani, S., Irwandani, I., Yuberti, Y., \& Widayanti, W. (2018). Kotak pop-up berbasis problem solving: pengembangan media pembelajaran pada materi cahaya dan alat-alat optik untuk kelas VIII SMP. Jurnal Pendidikan Matematika Dan IPA, 9(2), 98. https://doi.org/10.26418/jpmipa.v9i2.25847.

Muslimin, S., Rafiqah, R., \& Ikbal, M. S. (2018). Pengembangan lembar kerja peserta didik berbasis etnosains dengan model penalaran kausal untuk memecahkan masalah. JPF (Jurnal Pendidikan Fisika) Universitas Islam Negeri Alauddin Makassar, 6(1), 816. https://doi.org/10.24252/jpf.v6i1a2

Ningsih, W. K., Riyanto, Y., \& Suyanto, T. (2019). The development of pop up 3d general map using discovery learning models to improve creativity and learning outcomes of social studies grade V elementary school. International Journal of Scientific and

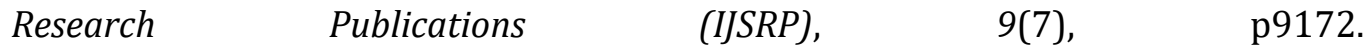
https://doi.org/10.29322/ijsrp.9.07.2019.p9172.

Nugroho, A., Raharjo, T., \& Wahyuningsih, D. (2013). Pengembangan media pembelajaran fisika menggunakan permainan ular tangga ditinjau dari motivasi belajar siswa kelas VIII materi gaya. Jurnal Pendidikan Fisika, 1(1), 11-18. Retrieved from https://jurnal.fkip.uns.ac.id/index.php/pfisika/article/view/1769/1265.

Nurfillaili, U., Yusuf, M., \& Santih, A. (2016). Pengembangan instrumen tes hasil belajar kognitif mata pelajaran fisika pada pokok bahasan usaha dan energi SMA Negeri Khusus Jeneponto Kelas XI Semester I. Jurnal Pendidikan Fisika, 4(2), 83-87. Retrieved from http://journal.uin-alauddin.ac.id/indeks.php/PendidikanFisika.

Nurliawaty, L., Mujasam, M., Yusuf, I., \& Widyaningsih, S. W. (2017). Lembar Kerja Peserta Didik (LKPD) berbasis problem solving Polya. JPI (Jurnal Pendidikan Indonesia), 6(1), 72-81. https://doi.org/10.23887/jpi-undiksha.v6i1.9183.

Rachmawati, E., Pramesti, G., Chrisnawati, H. E., \& Fitriana, L. (2019). Developing of the module based on the smash book by pop up with polyhedron's subject matter to improve students learning outcomes in mathematics. AIP Conference Proceedings, 2194(1), 020094-1-020094-020097. https://doi.org/10.1063/1.5139826.

Rafiqah. (2013). Pengembangan perangkat pembelajaran berbasis konstruktivisme. Makassar: Alauddin University Press.

Retnawati, H. (2016). Validitas reliabilitas dan karakteristik butir (Panduan untuk peneliti, mahasiswa, dan psikometrian). Yogyakarta: Parama Publishing.

Romanvican, M. G., Mundilarto, Supahar, \& Istiyono, E. (2020). Development learning media based traditional games engklek for achievements mastery of the material and tolerance attitude. Journal of Physics: Conference Series, 1440(1), 12044. https://doi.org/10.1088/1742-6596/1440/1/012044.

Safri, M., Sari, S. A., \& Marlina. (2017). Pengembangan media belajar pop-up book pada materi minyak bumi. Jurnal Pendidikan Sains Indonesia (Indonesian Journal of Science Education), 5(1), 107-113. Retrieved from http://www.jurnal.unsyiah.ac.id/JPSI/article/view/8431. 
Setyawan, D. (2014). Penerapan media pop up book untuk meningkatkan keterampilan berbicara pada siswa kelas II SDN 1 Wonoharjo Kemusu Boyolali Tahun Ajaran 2013/2014. Universitas Sebelas Maret.

Sinurat, M., Syahputra, E., \& Rajagukguk, W. (2015). Pengembangan media pembelajaran matematia berbantuan program flash untuk meningkatkan kemampuan matematik siswa SMP. Jurnal Pendidikan Tabulasarasa, 12(2), 1-12.

Suarti, Qaddaf, M., Rivai, I. N. A., \& Jusriana, A. (2020). Pengembangan Lembar Kegiatan Peserta Didik (LKPD) berbasis pendekatan saintifik pada materi fluida statis, elastisitas dan hukum Hooke. Jurnal Pendidikan Fisika, 8(1), 42-52. Retrieved from http://journal.uin-lauddin.ac.id/index.php/PendidikanFisika/article/view/12509

Sudijono, A. (2009). Pengantar evaluasi pendidikan. Jakarta: Rajagrafindo Persada.

Wamalwa, E. J., \& Wamalwa, E. W. (2014). Towards the utilization of instructional media for effective teaching and learning of english in Kenya. Journal of Education and Practice, 5(31), 2222. Retrieved from https://www.iiste.org/Journals/index.php/JEP/article/view/16698. 